\title{
U.S. Elections \\ and Russia-U.S. Relations
}

Can the Two Countries Break the Vicious Circle of Confrontation?

Dmitry V. Trenin

Dmitry V. Trenin is the Director of the Carnegie Moscow Center, a member of the International Institute for Strategic Studies (London, United Kingdom) and of the Russian International Affairs Council (Moscow, Russia).

DOI: $10.31278 / 1810-6374-2020-18-1-146-156$

The Soviet Union's prominent Americanist Georgy Arbatov once said: "The U.S. election is a bad time for a good policy and a

good time for a bad one." This rule was apparently coined to last. Anyhow, it still works. Moreover, the past four years provided ample proof that a "bad policy time" may last for a whole presidential term of office if the U.S. political class remains obsessed with acute internal strife that leaves virtually no room for sober-minded decisions and long-term strategies, including those in the realm of foreign policy. Whether this period will end in 2021 or last until the mid-2020s will be clear after the November 2020 election. For Russia, this factor is extremely important for shaping its own medium-term strategy on the American track. In a long-term perspective, it is essential that Russia thoroughly examine and take-subjunctive into account the experience of the past three to ten years.

In the foreseeable future, the internal political struggle in the United States will remain a hindrance to the stabilization of U.S.-Russian relations. Anti-Russian hysteria continues unabated. This is happening despite the fact that soberly-minded Americans agree that it is essential to restore dialogue with Russia and establish some sort of cooperation with 
it in addressing strategic stability issues (the future of the New START treaty) and other security-related matters, such as nuclear non-proliferation and resistance to terrorism. The problem is that such cooperation is regarded as a concession to Russia, which suggests that Moscow takes some steps first to meet U.S. demands, for instance, admit its interference in the 2016 election and pledge not to meddle in the U.S. political process ever again. This approach offers little chance for resuming a full-fledged political dialogue before the 2020 election, if at all.

The outcome of the election will not bring any fundamental change to U.S.-Russian relations, but may have different effects on them, depending on what kind of victory this or that candidate wins. If the incumbent president wins with a comfortable margin of $4 \%-5 \%$ of the electorate or more, his position will be consolidated to a point where he will have a free hand in conducting an independent policy, including in relations with Russia, without watching the reaction of the Democratic opposition. On the other hand, an impressive victory by a Democratic candidate will leave no chance for imputing it to Russia's meddling. With time, after "one or two years of hatred," such an outcome may tap some, albeit strictly limited, opportunities for resuming dialogue on military-political and counter-terrorism-related matters. Such a pragmatic dialogue would, of course, be counterbalanced (or camouflaged) by the Democrats' harsh public criticism of Russia's domestic and foreign policies in the media.

Trump's reelection for a second term by a narrow margin, or only in the Electoral College vote, and not by a majority of the electorate, will most probably start another season of the current "Cold Civil War" saga, in which Russia is doomed to play the part of Trump's evil stringpuller and, consequently a bitter enemy of the U.S. Democrats, the media and a larger part of the U.S. establishment. It remains anyone's guess to what extent Trump will manage to retain his professed interest in improving relations with Russia, and to what extent the Republicans in Congress will resist the Democrats' efforts to tighten the grip of sanctions on Russia.

A unique and rather precarious destabilizing situation may emerge if Trump refuses to recognize defeat and leave the White House, and even 
calls on his supporters-armed with civilian-held firearms-to defend the people's choice from the elites' encroachments. The history of the United States does not know such instances, but the situation already looks extraordinary as Trump has demonstrated he is prepared to defy any restrictions. In a situation like this some pundits pin hopes not on courts of law or other constitutional mechanisms of checks and balances, but on direct involvement of the military in defending the Constitution in order to depose the head of state reluctant to leave his seat.

In the current circumstances Moscow can hardly do anything to ease the situation with Russia's toxicity in U.S. politics. U.S. businesses operating in Russia remain profitable, but they prefer to keep a low profile in order to avoid attention on the part of sanctions enthusiasts in Congress. Potential American newcomers are afraid of investing in Russia for fear of sanctions and the risk of encountering Russia's internal problems lavishly depicted by the U.S. media. Changes for the better in this sphere may follow, but only in the long term, and only if Russia sets a course towards active economic development, privatization and de-monopolization-and on the condition of strengthening the independence of the judicial system. In this case economic attractiveness may overpower political enmity.

Outside of the political and media circles-mostly those in Washington-the perception of Russia as an outwardly hostile country is far weaker. In the U.S. intellectual community, above all in the university milieu, a revision of values, including foreign policy ones, is well underway. There have been some fundamental studies critical of liberal interventionism and militarism as distinguishing features of U.S. foreign policy of the past few decades. The issue on the agenda is not so much how best to conduct foreign policy as how to map a new course that would match global realities. These tendencies are not mainstream ones yet, but their very emergence is a telling sign.

However important the 2020 presidential election may be, in a sense it is only interim. It will highlight the vigorous political struggle and split in society, but it will fail to provide answers to the pressing questions. Exit from the three crises currently engulfing the United States-in politics, social ideology and foreign relations-will be long 
and painful. The point in question is that a whole era that began when Ronald Reagan moved into the White House is drawing to an end. In the economy this means the advent of neoliberalism of the "Chicago School;" in the social sphere, soaring social inequality-a situation where approximately 20 percent made considerable gains as a result of globalization while 80 percent broke even but considerably lost in contrast to the previous group; and in foreign policy, triumphalism resulting from the United States' sudden and complete victory in the Cold War.

The contours of a new balance in the economy and domestic and foreign policies of the United States are not in sight yet, but the process of change has been set in motion and we must keep a close watch on it as well as on the inevitable change of generations in the U.S. political class: all of the main contenders for the U.S. presidency-Donald Trump, Joe Biden, Elizabeth Warren, Bernie Sanders, and Michael Bloomberg-are over 70 . The 2024 presidential election, which will take place simultaneously with Russia's and the expected reconfiguration of power in Russia, may give birth to a new image of U.S. policy and create conditions for a new start in Russia-U.S. relations.

One of the powerful reasons for turning this page is the current condition of Russia-U.S. relations, which can be described in no way other than confrontation. However, this confrontation is different from that of the Cold War-it is mostly a conflict of interests, not an antagonism of ideologies.

The root cause of this standoff is the lack of a satisfactory settlement following the end of the Cold War. Having lost that confrontation under the name of the USSR, Russia refused to get integrated with the U.S.-centric system as the United States' junior partner. Moreover, it embarked on a policy of regaining the status of a great power. The winner in the Cold War, the United States, which had in fact already written off Russia as a major international actor, found Moscow's offer of partnership on parity terms utterly unacceptable. This is the most important factor about the end of the Cold War. Subjective mistakes and miscalculations were made on both sides, but they are of secondary importance. 


\section{THE PARTIES' POSITIONS AND MODE OF ACTION}

Russia asserts its right to determine, promote and defend its interests on its own. The United States is adamant to enforce the rules established after the Cold War. Russia's policies, specifically in relation to Ukraine and Syria, undermine and reduce to nothing the value of U.S. rules. Russia is unable to recognize the U.S.-centric world order, because it would be tantamount to recognizing its own vassal status. The United States is unable to either come to terms with Russia or to ignore its actions, because both would be tantamount to relinquishing global leadership upon which U.S. hegemony rests.

Russia's challenge to the United States fits in well with the current trend of nation states gaining more strength amid waning influence of the global institutions created by the U.S.-led West-the Pax Americana system. China's continuing rapid growth and India's looming rise are graphic illustrations of this trend. Some regional powers-Turkey, Iran, and Brazil-are rising as well. A certain drift towards independence is noticeable in Japan's foreign policy. In the longer term, the process of nation states gaining more muscle is likely to affect Europe, in particular, France and Germany.

The current Russian-U.S. standoff is a hybrid war. The main theaters of operation/domains of that war are informational, economic, financial, and technological. The United States relies on its colossal material superiority over Russia. The U.S. prefers to act straightforwardly and massively. Russia's actions are based on its leadership's awareness of the relative weakness as compared to the United States. Russia acts asymmetrically, with precision, and often successfully. Over the past five years Washington has failed in all of its attempts to force Moscow to considerably change its course in the desirable direction.

\section{PROSPECTS OF CONFRONTATION}

The current state of Russia-U.S. relations is grave but stable. Their further worsening is possible and even most likely, but a fatal turn may occur only as a result of a tragic coincidence of circumstances. A safety net protecting the two sides from a direct military clash does 
exist. There are permanent direct contacts between the top political leadership, military commands and the top officials in charge of the mechanisms that ensure the national security of Russia and the United States. It is very important that both countries act on the understanding that the current Russia-U.S. confrontation, however serious and potentially risky it might look, is not existential, in contrast to the Cold War.

The chances of a considerable improvement in relations between Russia and the United States within five to seven years look bleak. Anti-Russian sanctions have become law and will not be canceled for a very long time, in fact, never in the lifetime of the current generation of politicians in office. Russia's actions are pragmatic by and large and stem from its leadership's understanding of its national interests. Based on these interests, Moscow is prepared to cooperate with any countries as long as they respect Russia's interests and its status in the world. The problem is that it will be hopeless to expect Washington to adopt such an approach in the foreseeable future.

Of course, Russia and the United States, however obvious and insurmountable their distinctions may look, are not eternal and irreconcilable adversaries. Long-term prospects for ending the U.S.Russian confrontation depend first and foremost on the internal factors in either country. In the United States, the tendency to reduce global involvement and focus on increasing the competitiveness of the national basis (which began to show during the second presidency of George W. Bush, became obvious under President Barack Obama and prevails now that President Donald Trump is in office) is a longterm trend. This tendency signals the possibility for reformatting U.S. relations with its allies and partners and also with its competitors and rivals, including Russia.

Russia's attempts to regain the great power status in the world raise the question of how stable this status can be without sufficient economic success to rely on. Logically, the solution of this problem will require a reorientation of Russia's foreign policy towards the country's internal development, above all, economic and technological. This reorientation will require shifting attention from world order issues in general to Russia's place and role in the emerging world system. 
The country's security in the 21 st century, while relying on sufficient support of the nuclear and non-nuclear deterrence capabilities, will be increasingly determined by non-military parameters. The lesson of the Soviet Union should make Russia think more of the economy, technologies and social policies, as well as public sentiment.

If both of the abovementioned factors come to the fore in their respective countries, a situation may take shape at some future date, in the 2030s-2040s, where relations between Russia and U.S., while remaining essentially those of rivals (which is normal for great powers), may exit the phase of acute confrontation. Ideally, they may transform into ordinary relations between competitors, capable of maintaining selective pragmatic cooperation.

\section{CRUCIAL TASKS: STRATEGIC STABILITY}

Some steps towards easing tensions may be taken without waiting for the current standoff to end. There is a basis for this. Although the confrontation is continuing and occasionally intensifies, Russia and the United States are aware of the risk of a direct military conflict. Operational channels of communication and prevention of armed clashes have been established. Personal contacts are maintained between officials holding key positions in the armed forces and national security structures of their countries. Although there is no dialogue, certain communication is maintained.

The curtailment and possible abolition of arms control is a negative factor. Trying to preserve it will be a waste of time. In the modern conditions a new approach needs to be taken towards the problems of strategic stability instead of the one that was based on the realities of the second half of the 20th century. The main purpose of such an approach is prevention of armed conflicts between nuclear powers. The main methods of achieving this goal are on-line contacts and information exchanges between the countries concerned (the way it is done in relations between Russia and the United States); mutual restraint and unprovocative military activities; an information dialogue on military doctrines and strategies; cooperation in nuclear non-proliferation; joint activity in the prevention of nuclear terrorism. 
In the near future Russia and the United States should extend the New START treaty (scheduled to expire in February 2021) for another five years, enter into consultations on hypersonic weapons and outer space, and refrain from considering destabilizing deployment of intermediate and shorter-range missile systems outlawed by the INF Treaty. Also, it will be useful to start a permanent workshop discussion on strategic stability issues, which would enable both countries to achieve a better understanding of each other's strategies and doctrines.

\section{CHINA FACTOR}

Russia-U.S. confrontation reflects the spirit our times, but it is not its central conflict-in contrast to the standoff between the United States and China. It is U.S.-Chinese relations that have become the most important factor in shaping a new world order. Compared to both the United States and China, Russia is a relatively minor actor economically, technologically and demographically. Nevertheless, these three countries enjoy the greatest influence on the global geopolitical and military balances. In terms of economy and technologies, the United States and China hold the commanding positions, while Russia is an insignificant figure. For the United States it is China that is the main rival and potential enemy. Such a state of affairs creates both certain risks and opportunities for Russia.

Opportunities will open up there where the United States shifts its focus to China, thus paying less attention to Russia as a threat. Taking advantage of this opportunity is rather hard, though. Even if attention towards Russia eases, the attitude of the U.S. political elite to it remains strongly negative. Also, close cooperation between Russia and China in the military and military-technological spheres adds to the Americans' annoyance with Russia, which has ceased to be the number one opponent, but instead is helping America's number one adversary build its muscle.

The main risk is a possible emergence of a new bipolar model, in which Russia, which refused to be the United States' junior partner, might turn into a vassal of China. Washington's pressure on 
both Moscow and Beijing contributes to the implementation of this scenario. The opportunities for resisting this trend are rather limited, because the development of Russia's relations with other advanced countries-European ones and Japan-is restricted by these countries' allied solidarity with the United States. To a still greater extent Russia's economic relations are hindered by internal structural problems, which will be resolved one way or another but most probably beyond the foreseeable future.

In the new Washington-Beijing-Moscow triangle, Russia for the time being tries to remain an actor in its own right, although its relations with the United States and China are very different. How tightly Moscow and Beijing will coordinate their policies on the American track depends largely on U.S. policies. Russia appreciates its current relations with China and will not take the United States' side in its confrontation with China. There will be no new edition of Kissinger's "triangular diplomacy" beneficial to the United States. At the same time, it is obvious that amid harsh confrontation Russia at a certain point may lack the resources to push ahead with a policy of its own. There are enough reasons to say that double containment of Russia and China does not agree with America's strategic interests, either, but it has to be borne in mind that the United States' policies have not been strategically impeccable lately.

\section{IN SEARCH OF REGIONAL BALANCES}

If Russia succeeds in standing firm and retaining strategic independence, then its relations with the United States may bear fruit. A less global and more national-oriented approach by the United States to world affairs, while creating security vacuums in different parts of the world-the Middle and Near East, including the Persian Gulf, Afghanistan, and Northeast Asia and, to a great extent, Europe-may create conditions for Russian-U.S. cooperation within certain limits. Such interaction should not be exclusive. On the contrary, it may become part of multilateral efforts by leading actors to settle conflicts that endanger their fundamental interests. A new world order may be based on regional balances. 
For example, a balance in Europe can be gained through the settlement of the Ukraine crisis. The preconditions for such settlement are the recognition of Crimea's status as Russian territory and the reintegration of Donbass with Ukraine on the basis of the Minsk Accords of 2015. As a result, Ukraine would become a country neutral to both the U.S./NATO and Russia and an associated partner of the European Union with an opportunity to further develop its relations with the EU. The Ukraine conflict must be settled by the Ukrainians, Russians and Europeans (Germany and France above all, but not only), but the U.S. might make its own contribution to this cause. The most crucial move the United States would be required to make to this end would be an unequivocal promise to refrain from NATO's further eastward expansion. In fact, this expansion is already blocked by the obvious risk of a military clash and the United States' clear reluctance to shield countries that are secondary in terms of its national interests.

Similarly, reintegration in combination with power-sharing and military neutrality on the condition of unhampered relations with the European Union may constitute a successful solution of the Transnistrian conflict in Moldova. Removal of NATO's expansion issue from the agenda may pave the way for Georgia's association with Europe and at the same time ease tensions between Georgia and Abkhazia, Georgia and South Ossetia, and Georgia and Russia. As far as Belarus is concerned, it would remain an independent country having tight economic, political, military, and humanitarian bonds with Russia within the Union State, the CSTO and the EAEU, while retaining an opportunity to maintain diversified relations with the European Union.

In the Middle East, the United States may begin to cooperate with Russia in the same way as the regional states-Israel, Iran, Saudi Arabia, Turkey and many others-do. As before, Moscow and Washington share the goal of preventing nuclear arms proliferation in the region. Neither Russia nor the United States hopes for long-term gains from a war between Iran and Saudi Arabia. And, of course, the Middle East remains a hotbed of spawning radicalism, extremism and terrorism, 
which the United States and Russia find equally worrisome. The latter is entirely true of Afghanistan.

In Northeast Asia, stronger Russia-Japan relations might be useful for the United States at a time when China continues to gain strength. Moscow's partnership with Tokyo, just as close cooperation between Moscow and New Delhi, contribute to forming a more balanced situation in Asia, the Pacific and Indian Oceans and in the Arcticfrom Murmansk to Mumbai. The development of U.S.-Russian economic and other ties across the Pacific and Arctic Oceans would surely promote this, too.

In recent decades Russia has been too focused on the United States. Moscow initially had a strong desire to unite with it in friendship and harmony, but very soon it developed an equally strong urge to take revenge for its loss in the Cold War. Russian leaders and elites hopelessly expected that the United States would understand their problems and do the impossible-recognize Russia as an equal partner

On the eve of the third decade of the 21st century Russians should arm themselves with patience, set their eyes on the domestic affairs, and establish smooth and balanced relations with far stronger China. Or course, Moscow should closely monitor the situation in the United States, but by no means try to intervene in events there. Attempts at hacking into the political sanctum of other countries always triggers an outcry and almost never yields benefits. Keeping aloof from U.S. domestic policies is far more reasonable for Russia than getting involved in them. Changes in the internal and international situation in the next twenty years to come may force the United States to reconsider its modus operandi in the world arena. Then there may emerge a real basis for new Russia-U.S. relations of competition and interaction. For the time being it is strongly advisable for Russia to focus on gradually lessening the level of confrontation with the U.S. and, in the longer term, to look for conditions that would end it altogether. 